Fixed Point Theory, 22(2021), No. 1, 15-30

DOI: $10.24193 /$ fpt-ro.2021.1.02

http://www.math.ubbcluj.ro/ nodeacj/sfptcj.html

\title{
FIXED POINTS AND SETS OF MULTIVALUED CONTRACTIONS: AN ADVANCED SURVEY WITH SOME NEW RESULTS
}

\author{
JAN ANDRES*, JIŘÍ FIŠER** AND LECH GÓRNIEWICZ*** \\ *Department of Mathematical Analysis and Application of Mathematics, Faculty of Science, \\ Palacký University, 17. listopadu 12, 77146 Olomouc, Czech Republic \\ E-mail: jan.andres@upol.cz \\ ** Department of Mathematical Analysis and Application of Mathematics, Faculty of Science, \\ Palacký University, 17. listopadu 12, 77146 Olomouc, Czech Republic \\ E-mail: jiri.fiser@upol.cz \\ *** Faculty of Mathematics and Computer Sciences, Nicolas Copernicus University, \\ Chopina 12/18, 87-100 Toruń, Poland \\ E-mail: gorn@mat.uni.torun.pl
}

Dedicated to the memory of Professor Andrzej Granas (1929-2019)

\begin{abstract}
The existence of fixed points and, in particular, coupled fixed points is investigated for multivalued contractions in complete metric spaces. Multivalued coupled fractals are furthermore explored as coupled fixed points of certain induced operators in hyperspaces, i.e. as coupled compact subsets of the original spaces. The structure of fixed point sets is considered in terms of absolute retracts. We also formulate a continuation principle for multivalued contractions as a nonlinear alternative based on the topological essentiality. Two illustrative examples about coupled multivalued fractals are supplied.
\end{abstract}

Key Words and Phrases: Multivalued contractions, fixed points, coupled fixed points, coupled fractals, absolute retracts, continuation principle, essentiality.

2020 Mathematics Subject Classification: 28A80, 47H09, 47H10, 54C60, 55M15.

\section{REFERENCES}

[1] J. Andres, J. Fišer, Metric and topological multivalued fractals, Int. J. Bifurc. Chaos, 14(2004), no. 4, 1277-1289.

[2] J. Andres, L. Górniewicz, On the Banach contraction principle for multivalued mappings, In: Approximation, Optimization and Mathematical Economics. Proceedings of the 5th international conference on "Approximation and Optimization in the Caribbean", Guadeloupe, French West Indies, March 29 - April 2, 1999 (M. Lassonde, ed.), Physica-Verlag, Heidelberg, 2001, $1-23$.

[3] J. Andres, L. Górniewicz, Topological Fixed Point Principles for Boundary Value Problems, Serie: Topological Fixed Point Theory and Its Applications, Kluwer, Dordrecht, 2003.

The first author was supported by the grant IGA-PrF-2019-006 "Mathematical Models" of the Internal Grant Agency of Palacký University in Olomouc. 
[4] J. Andres, M. Rypka, Multivalued fractals and hyperfractals, Int. J. Bifurc. Chaos, 22(2012), no. 1, 1-27.

[5] R. Bielawski, Simplicial convexity and its applications, J. Math. Anal. Appl., 127(1987), 155171.

[6] K. Borsuk, Theory of Retracts, Polish Scientific Publishers, Warsaw, 1967.

[7] P. Chanthorn, P. Chaoba, Fixed point sets of set-valued mappings, Fixed Point Theory Appl., 56(2015), no. 2015-56, 1-16.

[8] H. Covitz, S.B. Nadler, Jr., Multi-valued contraction mappings in generalized metric spaces, Israel J. Math., 8(1970), 5-11.

[9] F.S. De Blasi, L. Górniewicz, G. Pianigiani, Extension theorems and topological essentiality in $\alpha$-convex metric spaces, Topol. Meth. Nonlin. Anal., 34(2009), 141-160.

[10] Z. Dzedzej, B. Gelman, Dimension of the solution set for differential inclusions, Demonstratio Math., 26(1993), 149-158.

[11] M. Frigon, A. Granas, Resultats du type Leray-Schauder pour des contractions multivoques, Topol. Meth. Nonlin. Anal., 4(1994), 197-208.

[12] M. Frigon, A. Granas, Z. Guennoun, An elementary proof of nonlinear alternative, Ann. Sci. Mat. Quebec, 19(1995), no. 1, 65-68.

[13] G. Gabor, L. Górniewicz, M. Slosarski, Generalized topological essentiality and coincidence points of multivalued maps, Set-Valued Anal., 17(2009), 1-19.

[14] L. Górniewicz, Topological Fixed Point Theory of Multivalued Mappings, 2nd ed., Springer, New York, Berlin/Heidelberg, 2006.

[15] L. Górniewicz, S. Marano, On the fixed point set of multivalued contractions, Rendioconti del Circolo Mat. di Palermo, Serie II, 49(1996), 139-135.

[16] L. Górniewicz, S. Marano, M. Slosarski, Fixed points of contractive multivalued mappings, Proc. Amer. Math. Soc., 124(1996), no. 9, 2675-2683.

[17] L. Górniewicz, M. Slosarski, Topological essentiality and differential inclusions, Bull. Austral. Math. Soc., 45(1992), 177-193.

[18] A. Granas, The theory of compact vector fields and some of its applications to topology of functional spaces (I), Diss. Math. 30, Polish Sci. Publ., Warsaw, 1962.

[19] A. Granas, Continuation method for contractive maps, Topol. Meth. Nonlin. Anal., 3(1994), 375-379.

[20] A. Granas, J. Dugundji, Fixed Point Theory, Springer, Berlin, 2003.

[21] D. Guo, V. Lakshmikantham, Coupled fixed points of nonlinear operators with applications, Nonlin. Anal., 11(1987), no. 5, 623-632.

[22] S. Hu, N.S. Papageorgiou, Handbook of Multivalued Analysis. Volume I: Theory, Kluwer, Dordrecht, 1997.

[23] W.A. Kirk, N. Shahzad, Continuation methods in certain metric and geodesic spaces, Bull. Math. Sci., 6(2016), no. 2, 311-323.

[24] W.A. Kirk, B. Sims (eds.), Handbook of Metric Fixed Point Theory, Kluwer, Dordrecht, 2001.

[25] D. Miklaszewski, The Role of Various Kinds of Continuity in the Fixed Point Theory of SetValued Mappings, Lecture Notes in Nonlinear Analysis, vol. 7, Toru, 2005.

[26] S.B. Nadler, Jr., Multivalued contraction mappings, Pacific J. Math., 30(1969), no. 2, 475-487.

[27] A. Petruşel, G. Petruşel, Coupled fixed points and coupled coincidence points via fixed point theory, Mathematical Analysis and Applications: Selected Topics (M. Ruzhansky, H. Dutta, and R.P. Agarwal, eds.), J. Wiley \& Sons, Inc., New York, 2018, 661-707.

[28] A. Petruşel, G. Petruşel, Coupled fractal dynamics via Meir-Keeler operators, Chaos, Solitons \& Fractals, 122(2019), 206-212.

[29] A. Petruşel, G. Petruşel, B. Samet, J.-C. Yao, Coupled fixed point theorems for symmetric multi-valued contractions in b-metric space with applications to systems of integral inclusions, J. Nonlin. Convex Anal., 17(2016), no. 7, 1265-1282.

[30] A. Petruşel, G. Petruşel, J.-C. Yao, A study of a system of operator inclusions via a fixed point approach and applications to functional-differential inclusions, Carpathian J. Math., 32 (2016), no. 3, 349-361. 
[31] A. Petruşel, A. Soos, Coupled fractals in complete metric spaces, Nonlinear Anal. Modelling and Control, 23(2018), no. 2, 141-158.

[32] B. Ricceri, Une propriete topologique de l'ensemble des points fixed d'une contraction multivoque à valeurs convexes, Atti Acad. Naz. Lincei VII, Ser. Cl. Sci. Fiz. Mat. Natur., 81(1987), no. 3, 283-286.

[33] I.A. Rus, Fixed Point Structure Theory, Cluj Univ. Press, Cluj-Napoca, 2006.

[34] I.A. Rus, A. Petruşel, G. Petruşel, Fixed Point Theory, Cluj Univ. Press, Cluj-Napoca, 2008.

[35] J. Saint Raymond, Points fixes des contractions multivoques, Fixed Point Theory and Appl. (J.B. Baillon and M.A. Thora, eds.), vol. 252, Pitman, Res. Notes in Math. Ser., Harlow, 1991, 359-375.

[36] J. Saint Raymond, Multivalued contractions, Set-Valued Anal., 4(1994), 559-571.

[37] B. Samet, C. Vetro, Coupled fixed point theorems for multi-valued nonlinear contraction mappings in partially ordered metric spaces, Nonlin. Anal., 74(2011), no. 12, 4260-4268.

[38] S. Thompson, An extension of Browder's nonejective fixed point theorem, Fixed Point Theory, 11(2020), 143-146.

[39] J.E. West, Hilbert cube manifolds - meeting ground of geometric topology and absolute neighbourhood retracts, Proc. Int. Congress of Mathematicians (O. Lehto, ed.), Academia Scientiarum Fennica, Helsinki, 1980, 497-503.

[40] H.-K. Xu, Metric fixed point theory for multivalued mappings, Diss. Math., 389, Polish Sci. Publ., Warsaw, 2000.

Received: March 11, 2019; Accepted: May 5, 2019. 